\title{
Carbonaceous Aerosol from Open Burning and its Impact on Regional Weather in South Asia
}

\author{
Prashant Singh $^{1,2}$, Pradip Sarawade ${ }^{1 *}$, Bhupesh Adhikary ${ }^{2 *}$ \\ ${ }^{I}$ Department of Physics, University of Mumbai, Mumbai 400098, India \\ ${ }^{2}$ International Centre for Integrated Mountain Development (ICIMOD), Khumaltar, Lalitpur, Nepal
}

\begin{abstract}
Seasonal open biomass burning contributes to significant carbonaceous aerosol loading over South Asia. This study analyzes long-term trends in emissions in two hot spot regions, Myanmar and Punjab, based on data from the Global Fire Emissions Database (GFED4s) and Fire INventory (FINN) from the National Center for Atmospheric Research (NCAR). Our analysis reveals that emissions during active fire seasons increase by approximately $83-106 \%$ and $2338-3054 \%$ for Punjab and Myanmar, respectively, compared to the estimates of anthropogenic emissions obtained with FINN. We also examine the impact of carbonaceous aerosol from open biomass burning on regional weather by using the Weather Research and Forecasting model coupled with Chemistry (WRF-Chem) to conduct a year-long simulation of the post-monsoon and pre-monsoon periods when active fires were reported. The results indicate that the carbonaceous aerosol is vertically lofted by as much as $3-5 \mathrm{~km}$ into the atmosphere and, rising as high as the $850 \mathrm{hPa}$ level from the surface, disperses horizontally throughout South Asia. Our calculations on the radiative forcing suggest that changes of up to $-6.14 \mathrm{~W} \mathrm{~m}^{-2}$ and $-0.50 \mathrm{~W} \mathrm{~m} \mathrm{~m}^{-2}$, and $-42.76 \mathrm{~W} \mathrm{~m}^{-2}$ and $-1.91 \mathrm{~W} \mathrm{~m}^{-2}$ occur at the surface and at the top of the atmosphere over Punjab and Myanmar, respectively. We also find that carbonaceous aerosol (black carbon + organic carbon), similar to black carbon (BC), reduces the surface temperature, despite the scattering effects of organic carbon (OC). Overall, open biomass burning causes the surface temperature to decrease by $2 \mathrm{~K}$, the relative humidity to increase by $8 \%$ and the planetary boundary layer height to change by as much as $600 \mathrm{~m}$. Changes in the precipitation patterns and volume due to the carbonaceous aerosol from open biomass burning, however, are negligible when considering only the direct radiative feedback.
\end{abstract}

Keywords: South Asia; Biomass burning; Carbonaceous aerosol; WRF-Chem.

\section{INTRODUCTION}

Carbonaceous aerosol (CA) is generally denoted as black carbon $(\mathrm{BC})$ and organic carbon (OC), and together $\mathrm{OC}$ and $\mathrm{BC}$ play an important role in weather and climate systems of the atmosphere (Penner, 1994; Vadrevu et al., 2015). Major components of carbonaceous aerosol come from anthropogenic activities or sources (Streets et al., 2003a; Bond et al., 2007; Ramanathan and Carmichael, 2008; Sharma et al., 2014). During specific months, open biomass burning becomes the source of loading of a significant amount of carbonaceous aerosol in the atmosphere (Reid et al., 1998; Duncan, 2003; Hoelzemann et al., 2004; Song et al., 2010; Reddy et al., 2012; Jain et al., 2014; Liu et al., 2014; Putero et al., 2014; Sahu et al., 2015; Zhang et al., 2015). Carbonaceous aerosol

\footnotetext{
${ }^{*}$ Corresponding author.

Tel.: (977)15275222; Fax: (977)15275238

E-mail address: bhupesh.adhikary@icimod.org; pradip.sarawade@physics.mu.ac.in
}

from open biomass burning are co-emitted along with both long- and short-lived climate forcers such as carbon dioxide $\left(\mathrm{CO}_{2}\right)$, carbon monoxide $(\mathrm{CO})$, sulfur dioxide $\left(\mathrm{SO}_{2}\right)$, reactive nitrogen $\left(\mathrm{NO}_{x}, \mathrm{NO}_{y}, \mathrm{PANs}\right.$, and $\left.\mathrm{HNO}_{3}\right)$ etc. (Potter et al., 2001; Karl et al., 2007; Goldammer et al., 2008; Chang and Song, 2010; Kondo et al., 2011). Emissions from biomass burning in Southeast Asia rise up to $\sim 3 \mathrm{~km}$ (Lin et al., 2009). Similar uplifting of open biomass burning (OBB) emission was reported over Africa (Haywood et al., 2008) and Amazonia (Liu et al., 2014).

Hydrophobic BC strongly absorbs radiation and makes a direct impact by heating the atmospheric column, whereas hydrophilic BC contributes to ice nucleation (IC) in clouds (Chen and Bond, 2010; Bond et al., 2013; Guha et al., 2015). Hydrophobic OC mostly scatters solar radiation while a significant fraction of $\mathrm{OC}$ is also known to absorb a fraction of the radiation known as brown carbon and creating a surface cooling effect. Hydrophilic OC also acts as cloud condensation nuclei (CCN) (Penner, 1994; Ellison et al., 1999; Chen and Bond, 2010). Climate forcing over snow and ice due to carbonaceous aerosol deposition have also been reported in previous studies (Hansen and Nazarenko, 2004; 
Bond et al., 2013). In addition, the presence of absorbing aerosol such as BC near clouds can evaporate clouds by heating them (Conant et al., 2002; Koch and Del Genio, 2010). Results from the Precipitation Driver Response Model Inter-comparison Project (PDRMIP) suggest that climate forcing from $\mathrm{BC}$ affects precipitation patterns outside the emission source region of BC (Liu et al., 2018). Previous studies also indicate that $\sim 1 \mathrm{~K}$ temperature change near the surface can alter the water vapor content by $\sim 5 \%$ (Andrews et al., 2010; O'Gorman et al., 2012).

Current understanding of emissions of carbonaceous aerosol from open burning shows two regional hot spots relevant to South Asia (Venkataraman et al., 2006; Chang and Song, 2010; Jain et al., 2014). They are the Indo-Gangetic Plain (IGP), and in and around Myanmar in Southeast Asia. Among Asian countries, Myanmar is known as the biggest source of forest fires during the months of March and April (Biswas et al., 2015; Vadrevu et al., 2015). Emissions from agricultural residue (biomass) burning over Myanmar in both dry and wet seasons is much lower compared to forest fires (Chang and Song, 2010; Song et al., 2010; Kim Oanh et al., 2018). In contrast, crop residue burning during AprilMay and October-November over IGP causes a serious air quality problem, especially in October-November when the planetary boundary layer (PBL) is low (Sharma et al., 2010; Rajput et al., 2014; Singh and Kaskaoutis, 2014). Over South Asia (Bangladesh, Bhutan, India, Myanmar, Nepal, and Pakistan), $\mathrm{BC}$ emission from non-agricultural open fire is $\sim 11.62 \mathrm{Gg}$ year $^{-1}$ whereas $\mathrm{OC}$ emission is estimated at $\sim 106.17 \mathrm{Gg}$ year $^{-1}$ (Song et al., 2010). Total emission from open biomass burning (OBB) is estimated to be $\mathrm{BC}$ at $\sim 150 \mathrm{Gg}$ and $\mathrm{OC}$ at $\sim 1151 \mathrm{Gg}$ for South Asia (Streets et al., 2003b). Furthermore, BC emission from crop residue burning is estimated at $\sim 68 \mathrm{Gg}_{\text {year }}{ }^{-1}$ during 2008-2009 over India (Jain et al., 2014) whereas it was $14 \mathrm{Gg}_{\text {year }}{ }^{-1}$ during 2010 2015 over Myanmar (Kim Oanh et al., 2018). Over India, OBB contribute a total BC emission of 104-409 $\mathrm{Gg}_{\text {year }}{ }^{-1}$ and OC emission of 399-1529 Gg year ${ }^{-1}$ (Venkataraman et al., 2006). In contrast, in Myanmar, OBB contributes a total BC emission of $\sim 59 \mathrm{Gg}_{\text {year }}{ }^{-1}$ and OC emission of $\sim 590 \mathrm{Gg} \mathrm{year}^{-1}$ (Kim Oanh et al., 2018).

Earlier studies have reported on local and regional pollution events due to forest fires and agricultural biomass burning (Goldammer et al., 2008; Reddington et al., 2014). But most of these have been limited to characterization and estimation of emission from OBB (forest and crop residue burning) (Venkataraman et al., 2006; Song et al., 2010; Vadrevu et al., 2015). Moreover, some studies on Southeast Asia were limited to transport of emissions from OBB which have implications for urban and regional air quality (Sahu et al., 2015; Zhou et al., 2018). Menon et al. (2002) reported the impact of BC on regional precipitation over India and China. Recently Liu et al. (2018) and Andrews et al. (2010) have simulated the climatic effects of hypothetical $10 \times \mathrm{BC}$ (where anthropogenic $\mathrm{BC}$ emission was increased by a factor of 10) on regional weather and climate. The present study investigates a case of high carbonaceous aerosol $(\mathrm{BC}+\mathrm{OC})$ in the atmosphere emitted from OBB during the pre- and postmonsoon periods and its impact on the weather over South
Asia. While the hypothetical high BC emission case studies were carried out using a global chemistry-climate model, we tried to understand the impact of high $\mathrm{BC}$ emission using a high-resolution regional weather forecasting model coupled with chemistry (WRF-Chem) in this study. This study does not prescribe hypothetical carbonaceous aerosol emissions to understand the impact of carbonaceous aerosol on radiation like previous studies. Instead, we estimated an increase in carbonaceous aerosol emissions from OBB regardless of the magnitude in this study. We also analyzed results from two different OBB inventories over South Asia which indicate the difference in emission strength. We present the vertical concentration of carbonaceous aerosol over South Asia as have been done in prior studies (Ramanathan et al., 2001; Chung et al., 2010) in order to estimate the vertical profile of CA from OBB and its impact on radiative forcing over South Asia. Further, we discuss in detail the impact of carbonaceous aerosol on regional weather and meteorological parameters.

\section{OBSERVATION AND METHODOLOGY}

\section{Fire Observations}

We use information from the monthly gridded Global Fire Emissions Database (version 4.1) (GFED4s), from 1997 to 2015, for analysis (Giglio et al., 2013). This data set is available at $0.25^{\circ}$ resolution and was downloaded from EARTHDATA website (https://daac.ornl.gov/cgi-bin/dsvie wer.pl?ds_id=1293). This set of data provides total carbon $\left(\mathrm{g} \mathrm{C} \mathrm{m}^{-2}\right.$ month $^{-1}$ ) and dry matter $\left(\mathrm{kg} \mathrm{DM} \mathrm{m}{ }^{-2}\right.$ month $\left.^{-1}\right)$ emissions from open fires globally. It includes emissions from different sources such as grassland and savanna, woodland, deforested and degraded areas, forests, agricultural waste burning, and peat fires. The Moderate Resolution Imaging Spectroradiometer (MODIS) burned area map, along with Tropical Rainfall Measuring Mission (TRMM), Visible and Infrared Scanner (VIRS) and Along-Track Scanning Radiometer (ATSR) data were used to generate this GFED data set (Giglio et al., 2013).

The Fire INventory from NCAR (version 1.0) (FINNv1) available at $1 \mathrm{~km}$ resolution was also used in this study (Wiedinmyer et al., 2011). This data set was downloaded from UCAR website (http://bai.acom.ucar.edu/Data/fire/). The data contains trace gas and particle emissions from various sources of open burning like wildfire, agricultural fires, and managed burnings (Wiedinmyer et al., 2011). MODIS Rapid Response data was used to identify fire location and time for FINN data set.

Additionally, the Copernicus Atmospheric Monitoring Service (CAMS) Global Fire Assimilation System (GFAS) data set is also used in this study. It was downloaded from CAMS-GFAS website (https://apps.ecmwf.int/datasets/data/ cams-gfas/). The CAMS-GFAS data set contains the wildfire flux of $\sim 40$ species at the $0.1^{\circ}$ special resolution at a daily resolution. The MODIS generated fire radiative power is used in GFAS to generate the emission product (Di Giuseppe et al., 2018). We used CAMS-GFAS data for the months of March, April, October and November of 2013 in the analysis. 
The Cloud-Aerosol Lidar and Infrared Pathfinder Satellite Observation (CALIPSO) uses active lidar and passive infrared sensors to measure the vertical profile of the atmosphere. We used CALIPSO images from the CALIPSO website (https:/www-calipso.larc.nasa.gov/products/lidar/b rowse_images/production/) to understand fire emissions, during the active biomass burning events in this study, from the available satellite overpass. Specifically, CALIPSO level 1 version 3.3 data with air pollution speciation (clean marine, dust, polluted continental, clean continental, polluted dust and smoke) was used in this study.

\section{Chemical Transport Model}

The Weather Research Forecasting model coupled with Chemistry (WRF-Chem version 3.8.1) is used in this study (Grell et al., 2005; Skamarock et al., 2008). Fig. 1 shows the model domain projected on Mercator projection centered at $22^{\circ} \mathrm{N}, 78^{\circ} \mathrm{E}$ which covers $6.5-36.0^{\circ} \mathrm{N}$ and $53.0-103.0^{\circ} \mathrm{E}$ on a spatial resolution of $25 \mathrm{~km}$. The model contains 40 vertical levels from surface to model top at $50 \mathrm{hPa}$. The heights of the first 10 levels are within $300 \mathrm{~m}$ each and all levels above are within $650 \mathrm{~m}$ each.

The Emission Database from Global Atmospheric ResearchHemispheric Transport of Air Pollution (EDGAR-HTAP) offers anthropogenic emission at $0.1^{\circ} \times 0.1^{\circ}$ spatial resolution for the year 2010 (Janssens-Maenhout et al., 2013). We used the EDGAR-HTAP emissions in this study using the preprocessor tool available from the NCAR website (Kumar et al., 2015). We have updated the initial and boundary condition in simulations for this study using the simulations from the Model for Ozone and Related chemical Tracers, version 4 (Mozart-4) (Emmons et al., 2010). $\mathrm{O}_{2}$ and $\mathrm{O}_{3}$ column densities from exo_coldens are used for photolysis processes in the MOZART/MOZCART option in the WRF-Chem simulation. The exo_coldens tools read $\mathrm{O}_{2}$ and $\mathrm{O}_{3}$ from the WRF input file and MOZART data is used to calculate column density and create a separate file. We use the monthly biogenic emission flux from the Model of Emissions of Gases and Aerosols from Nature version 2.1 (MEGAN2.1) in the WRF-Chem simulation for this study (Guenther et al., 2012). The daily sea surface temperature (SST) was updated in the model simulation using data from NOAA website (http://polar.ncep.noaa.gov/mmab/translation.shtml).

We use the MOZCART based chemistry option in the WRFChem simulation for this study. MOZCART is a combination of the MOZART model (for trace gas chemistry) and the Goddard Chemistry Aerosol Radiation and Transport (GOCART) model (for bulk aerosols chemistry). Dust emission is selected as suggested in GOCART chemistry and provided with fractional erosion map. Dimethyl sulfide (DMS) emissions are kept active in all the simulations (Chin et al., 2000).

The simulations for this study incorporates the emission estimate from FINNv1 which provides daily open burning emission at $1 \mathrm{~km} \times 1 \mathrm{~km}$ spatial resolution (https://www2.ac om.ucar.edu/modeling/finn-fire-inventory-ncar) (Wiedinmyer et al., 2011). Both smoldering and flaming emissions are included in the mapped data set. We use the MOZCART-based biomass burning emission and plume rise calculation for FINNv1 data as mentioned above. Physics parameterization options used in the simulation is provided in Table 1.

\section{METHODOLOGY}

We used the FINN and GFED monthly biomass burning carbonaceous emissions from 1997 to 2015 to identify and analyze fire hot spots over South Asia (6.5-36.0 ${ }^{\circ} \mathrm{N}, 53.0$ $\left.103.0^{\circ} \mathrm{E}\right)$. On the basis of GFED and FINN, Punjab (28.83$\left.32.01^{\circ} \mathrm{N}, 72.91-77.86^{\circ} \mathrm{E}\right)$ and Myanmar $\left(13.86-27.74^{\circ} \mathrm{N}\right.$, $\left.90.28-102.69^{\circ} \mathrm{E}\right)$ were identified as hot spots for biomass burning. Given the temporal and spatial similarity of the fires, this study only used FINN fire emissions for further analysis. We used the fire_emis source code from NCAR site to map FINN data set from 2002 to 2015 on input file at an hourly temporal resolution.

We carried out two sets of year-long simulations with the WRF-Chem model for 2013. The first set of simulations were carried out with total emissions (anthropogenic + OBB) of all air pollutants including carbonaceous species while the second experiment was simulated by omitting only carbonaceous aerosol from OBB. In both the model simulations, we used data from National Centers for Environmental Prediction Final Analysis (NCEP FNL) to update initial and boundary meteorological condition. To preserve similar meteorology in both simulations and avoid divergence in meteorological parameters, simulations were reinitialized every day with NCEP FNL data, whereas chemistry was carried forward from the last step of every previous day's simulation to maintain consistency in the vertical and horizontal concentration of chemical species. The chemical boundary condition was updated using MOZART output for each time step. This algorithm was followed in both simulations throughout the

Table 1. WRF-Chem Model Parameterization option used in this study.

\begin{tabular}{lll}
\hline Parameterization & Scheme & Reference \\
\hline Bulk microphysical parameterization & Thompson scheme & (Thompson et al., 2008) \\
Convective parameterization & Kain-Fritsch Scheme & (Kain, 2004) \\
Planetary boundary layer (PBL) & Yonsei University Scheme & (Hong et al., 2006) \\
Shortwave radiation physics & Dudhia Shortwave Scheme & (Dudhia, 1989) \\
Longwave radiation physics & RRTM Longwave Scheme & (Mlawer et al., 1997) \\
Land-atmosphere interaction & Unified Noah Land Surface Model scheme & (Tewari et al., 2004) \\
Surface layer option & MM5 & (Paulson, 1970) \\
Photolysis & Madronich Fast Tropospheric Ultraviolet-Visible & (Madronich and Weller, \\
& Model (F-TUV) & 1990) \\
\hline
\end{tabular}


year in order to maintain meteorology and chemistry consistency. The WRF-Chem simulations of meteorology and chemistry have been compared in detail in several other studies (Adhikary et al., 2007; Kumar et al., 2015).

\section{RESULTS AND DISCUSSION}

Fig. 1(a) shows the averaged total carbon emissions ( $\mathrm{g} \mathrm{C} \mathrm{m}^{-2}$ month $^{-1}$ ) from biomass burning from 1997 to 2015 using GFED4. Burning over Myanmar shows the highest carbonaceous emission within the domain. Carbonaceous emissions due to biomass burning from Punjab (both Pakistan and India) to Bihar (India) also show elevated emissions. Apart from Myanmar and Punjab (IGP), Fig. 1(a) also shows biomass burning emission over the Western Ghats (WG), Eastern Ghats (EG) and Sri Lanka. Fig. 1(b) shows biomass burning carbonaceous aerosol emission $\left(\mathrm{g} \mathrm{C} \mathrm{m}^{-2}\right.$ month $\left.^{-1}\right)$ from the FINN data set averaged for the 2002-2015 period. Despite differences in input data sets (MODIS/VIIRS/TRMM etc.) both FINN and GFED4 identify similar features within Myanmar and Punjab regions. The CAMS data set for 2013 (Fig. 1(c)) shows similar features illustrating 2013 as a normal year at least in spatial emission patterns when compared to climatology data sets. All three data sets use similar kinds of satellite observation, but different algorithms to define the area of coverage and emissions from open biomass burning.

Myanmar biomass burning episodes mostly results from forest fires during the dry and hot days of the pre-monsoon season (Liu et al., 2010; Biswas et al., 2015; Vadrevu et al., 2015). In contrast, Punjab biomass burning is a result of agricultural crop residue burning in April-May when the wheat crop is harvested, and during October-November when the rice crop is harvested (Venkataraman et al., 2006; Rajput et al., 2014; Tiwari et al., 2016). October-November biomass burning in Punjab is often in the news and media reports because of the deteriorating air quality situation in the IGP (Sharma et al., 2010; Singh and Kaskaoutis, 2014; Vadrevu and Lasko, 2018). Emissions during the months of March and April are under less scrutiny due to the convectively active season which transports the pollutants in the vertical layers unlike in the winter season (Vadrevu et al., 2015).

Furthermore, area-averaged OBB emissions from Punjab $\left(28.83-32.01^{\circ} \mathrm{N}, 72.91-77.86^{\circ} \mathrm{E}\right)$ and Myanmar (13.86$27.74^{\circ} \mathrm{N}, 90.28-102.69^{\circ} \mathrm{E}$ ), for the period of January $2002-$ December 2015 is presented in Fig. 1(d). It shows a single.
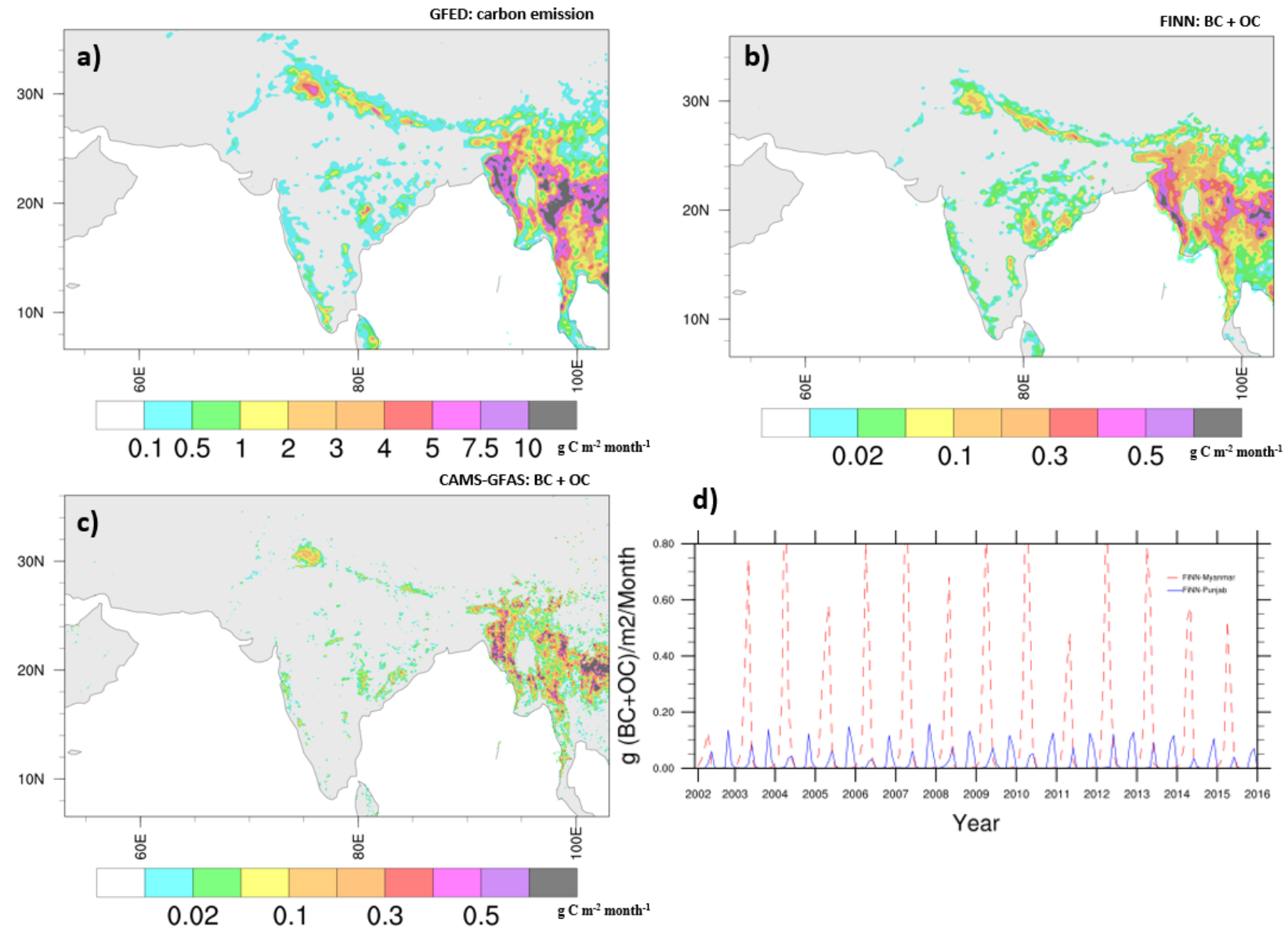

d)

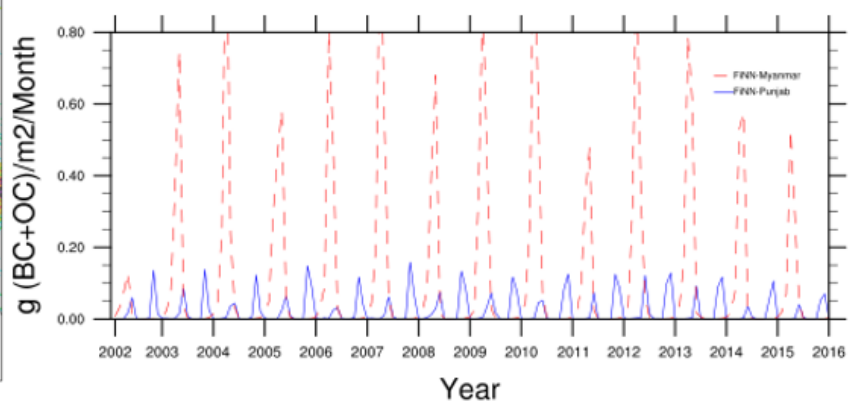

Fig. 1. Long-term average of carbonaceous aerosol emission from open biomass burning (OBB): (a) GFED monthly average total carbon emission from 1997-2015, (b) FINN average carbonaceous (black + organic) aerosol emission rates from 20022015, (c) area-averaged carbonaceous (black + organic) aerosol emission from CAMS and (d) climatology of carbonaceous aerosol (black + organic) from FINN model for Punjab and Myanmar regions. 
fire season over Myanmar starting in February and continuing till the onset of the monsoons. March is recorded as the highest OBB in Myanmar followed by April and February. Unlike Myanmar, Punjab shows two biomass burning seasons, the first in April-May and the second in October-November Table 2 shows the emission strength from open burning within these two model subdomains compared to anthropogenic emissions. The results in the parentheses show the lean burning seasons, which are March-April for Punjab and OctoberNovember for Myanmar. The analysis of the emissions during active fire seasons reveals that the Punjab emissions increase approximately $83-106 \%$ compared to anthropogenic emissions in the FINN model ( $26-50 \%$ from CAMS) while the Myanmar emissions increase by $2338-3054 \%$ in the FINN model (476-735\% from CAMS). These results show a real-world example of $10 \times \mathrm{BC}$ climate simulations as carried out by the PDRMIP studies but applicable to current weather timescales.

Given the uncertainty of the emissions from biomass burning (Wiedinmyer et al., 2011; Giglio et al., 2013; Di Giuseppe et al., 2018), we proceed with further analysis using FINN model emissions to estimate the impact on weather. The simulations include biomass burning emissions and plume rise calculation for MOZCART (biomass_burn_opt $=2)$. The model considers the fire emission as surface emission in the simulation whereas the injection height of OBB emission depends on the stability of the atmosphere and vertical winds (Archer-Nicholls et al., 2015; Walter et al., 2016). Generally, injection height shows a strong diurnal cycle depending on PBL stability and varies $2-3 \mathrm{~km}$ in height which is usually above the PBL (Grell et al., 2011). As discussed in the model setup section the height of each vertical level (the first 10 levels) in the model simulations are less than $300 \mathrm{~m}$ to capture the stability and mixing in of PBL layers while the height of vertical levels above PBL (mostly the $11^{\text {th }}$ level onwards) are below $650 \mathrm{~m}$. The injection height of OBB emission strongly depends on thermodynamic stability and PBL dynamics while uncertainty related to PBL height and thermal stability can affect the vertical distribution of BC. The GFED files are available on monthly timescales but are too coarse in terms of a temporal resolution for us to assess its impact on weather while the CAMS emissions were much lower than FINN to pick up significant alterations in weather variables. Hence, further results and discussions are limited to the period March-April for Myanmar, and October-November for the Punjab region.

Fig. 2 shows a vertical BC concentration area average for Myanmar (March-April 2013) and Punjab (October-
November 2013). Fig. 2(a) shows model simulations of BC concentration over Myanmar from the control run which includes biomass burning while Fig. 2(b) shows the concentration without biomass burning emissions. Similarly, Figs. 2(c) and 2(d) shows BC concentration from the control run and simulation without biomass burning emissions for the Punjab region. Fig. 2(a) shows significantly higher surface and boundary layer $\mathrm{BC}$ concentrations when compared to Fig. 2(b). Similar results are presented in Figs. 2(c)-2(d). Fig. 2(d) shows that BC concentrations are very high (black color scale) for a few days in mid-October to mid-November indicating that significant emissions from the Punjab region are limited to few days and not spread throughout the postmonsoon period. Moreover, CALIPSO passes over Myanmar shows that most days of March and April consist of smoke up to $5 \mathrm{~km}$ (supporting Fig. S1) whereas passes over Punjab during October-November shows the presence of smoke below $3 \mathrm{~km}$ (supporting Fig. S2). A similar smoke plume height is reported over India and Southeast Asia in another study (Vadrevu et al., 2015; Lee et al., 2016). Organic carbon concentration over Myanmar and Punjab show similar trends and spatial distribution albeit at higher concentration than BC.

While Fig. 2 shows subdomain (Punjab and Myanmar)averaged vertical profile of BC, Fig. 3 shows differences in plots of monthly averaged $\mathrm{BC}$ concentration between the control and experiment (no OBB emission) simulations at different vertical layers indicating the horizontal spread of $\mathrm{BC}$ aerosol. Rows illustrate concentration differences over several months while columns report vertical levels. At the surface, during March and April, differences in BC concentration in and around Myanmar show a north-south gradient. Elevated concentration differences are also seen along the eastern Indian shoreline in the Bay of Bengal. At $850 \mathrm{hPa}$ which is near PBL, results show similar features as the surface. Surface and $850 \mathrm{hPa}$ results show that $\mathrm{BC}$ emitted from OBB during the March and April fires affect mostly the eastern and the southern part of the domain. Furthermore, at 500 and $300 \mathrm{hPa}$ differences in $\mathrm{BC}$ concentration are still shown by the model, although diminishing over the Bay of Bengal at the $300 \mathrm{hPa}$.

Similarly, the third and fourth rows in Fig. 3 show monthly averaged differences in $\mathrm{BC}$ concentration for October and November respectively. At the surface, the results show prominent features around the Punjab region with a sharp north-to-south gradient. The difference in concentration between the two simulations is not as strong over the entire domain as that for fires from the Myanmar region. The $850 \mathrm{hPa}$ subplot shows similar features as the surface with lower

Table 2. Comparison of carbonaceous aerosol emission with anthropogenic emissions and different fire emission model estimates.

\begin{tabular}{|c|c|c|c|c|}
\hline Region & $\begin{array}{l}\text { Anthropogenic } \\
\left(\mathrm{g} \mathrm{m}^{-2} \text { month }^{-1}\right) \\
(\mathrm{BC}+\mathrm{OC})\end{array}$ & $\begin{array}{l}\text { FINN Emission } \\
\left(\mathrm{g} \mathrm{m}^{-2} \text { month }^{-1}\right) \\
(\mathrm{BC}+\mathrm{OC})\end{array}$ & $\begin{array}{l}\text { CAMS } \\
\left(\mathrm{g} \mathrm{m}^{-2} \text { month }^{-1}\right) \\
(\mathrm{BC}+\mathrm{OC})\end{array}$ & $\begin{array}{l}\text { GFED Emission } \\
\left(\mathrm{g} \mathrm{m}^{-2} \text { month }^{-1}\right) \\
\text { (carbon emissions) }\end{array}$ \\
\hline Myanmar & 0.03 & $\begin{array}{l}0.62-0.81 \\
(0.0011-0.0019)\end{array}$ & $\begin{array}{l}0.13-0.19 \\
(0.0002-0.0005)\end{array}$ & $\begin{array}{l}9.91-12.71 \\
(0.0319-0.0775)\end{array}$ \\
\hline Punjab & 0.11 & $\begin{array}{l}0.091-0.12 \\
(0.0019-0.0038)\end{array}$ & $\begin{array}{l}0.03-0.05 \\
(0.0001-0.0013)\end{array}$ & $\begin{array}{l}1.59-5.59 \\
(0.044-0.2250)\end{array}$ \\
\hline
\end{tabular}



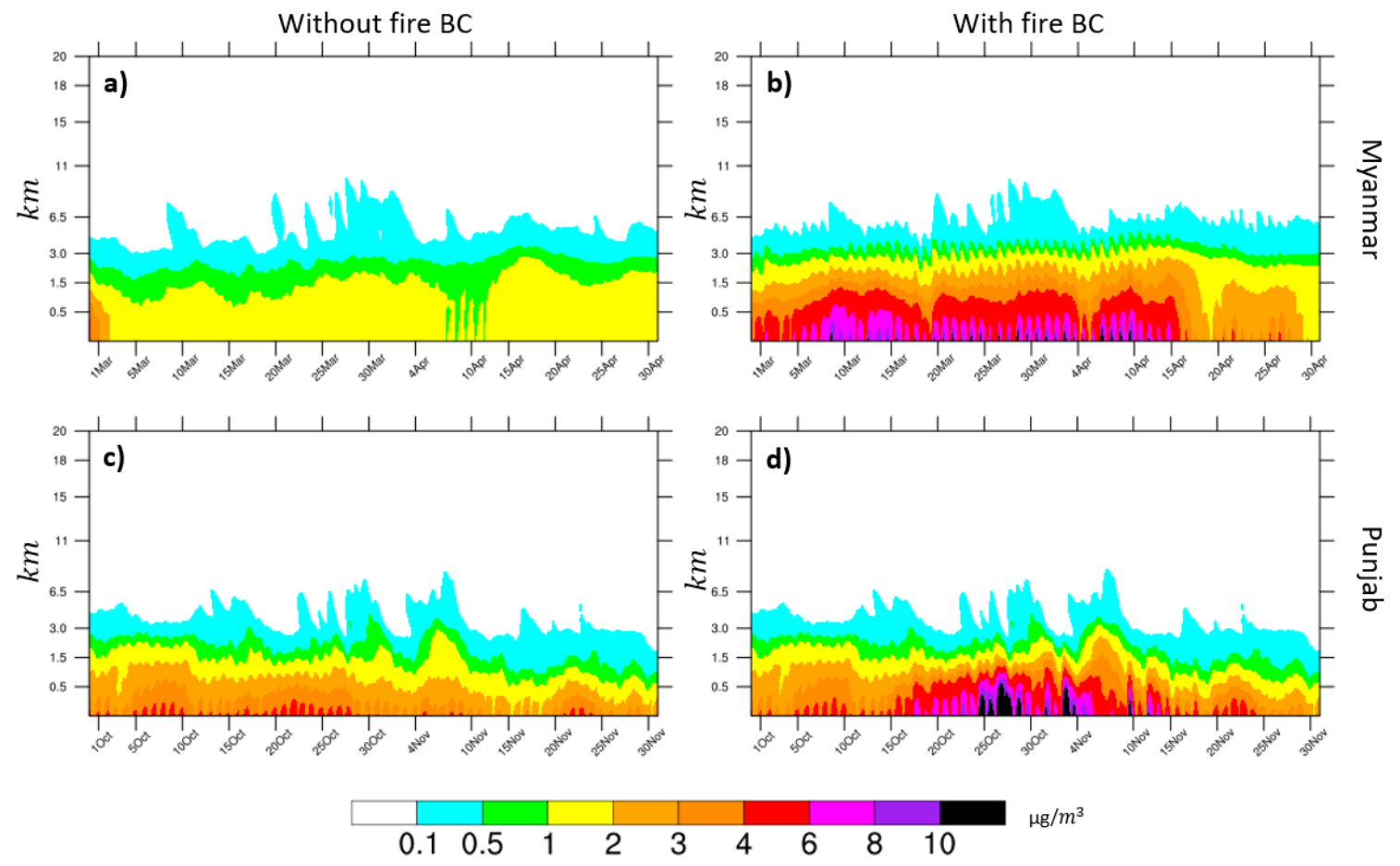

Fig. 2. Area-averaged BC concentration: (a) Myanmar control run, (b) Myanmar without OBB BC, (c) Punjab control run and (d) Punjab without OBB BC.
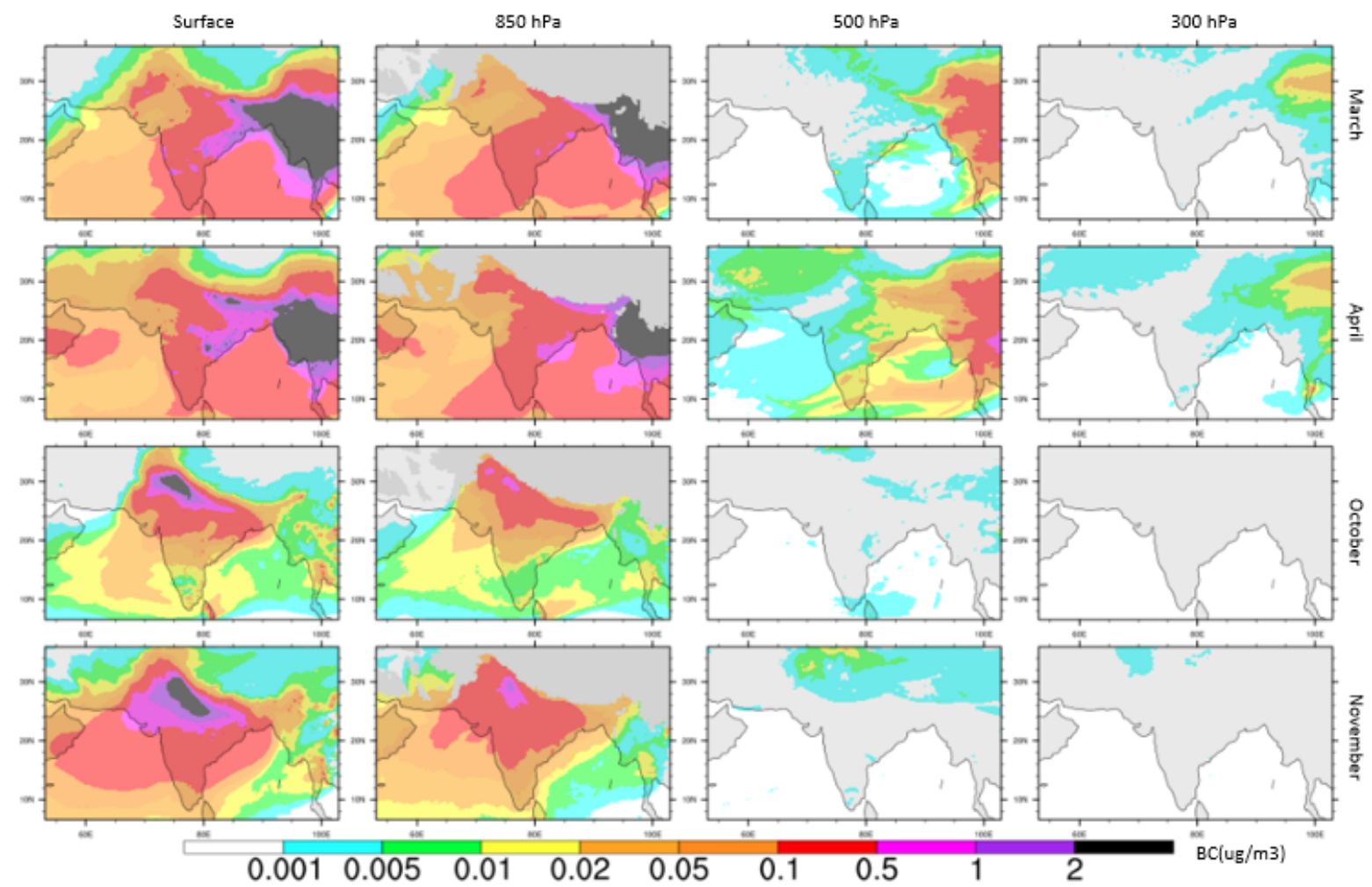

Fig. 3. Atmospheric loading of $\mathrm{BC}$ from $\mathrm{OBB}$ at (a) the surface, (b) $850 \mathrm{hPa}$, (c) $500 \mathrm{hPa}$ and (d) $300 \mathrm{hPa}$.

magnitude. The weak northerly winds (figure not shown) over the surface and the $850 \mathrm{hPa}$ prevent dispersion of $\mathrm{BC}$ concentration towards the northern portion of the modeling domain. A small amount of BC concentration from OBB is observed over the Tibetan Plateau (TP) at $500 \mathrm{hPa}$ whereas $300 \mathrm{hPa}$ remains clean. Similar trends are observed for OC at surface, $850 \mathrm{hPa}, 500 \mathrm{hPa}$ and $300 \mathrm{hPa}$ for all the four months (supporting Fig. S5), although the observed OC 
concentration is much higher $(\sim 4 \times)$ than that for BC. Such amount of $\mathrm{BC}$ and $\mathrm{OC}$ at surface and column levels can affect the incoming shortwave and outgoing longwave radiation budget, which may feed back into local meteorology (Ramanathan and Carmichael, 2008).

Table 3 shows the area-averaged impact of carbonaceous aerosol from OBB on incoming shortwave and outgoing longwave flux over the entire modeling domain and within the source regions. Our results show that the outgoing longwave radiation (OLR) flux reduces by $0.28 \mathrm{~W} \mathrm{~m}^{-2}$ over the entire modeling domain while it further reduced by $1.91 \mathrm{~W} \mathrm{~m}^{-2}$ over the source region. Ramanathan et al. (2005) reported top of the atmosphere (TOA) BC forcing to be $\pm 1 \mathrm{~W} \mathrm{~m}^{-2}$ for South Asia. Although Chung et al. (2010) have reported $-4.2 \mathrm{~W} \mathrm{~m}^{-2} \mathrm{TOA}$ radiative forcing due to anthropogenic aerosol, the $\mathrm{BC}$ radiative forcing reported is $+2.1 \mathrm{~W} \mathrm{~m}^{-2}$ for Asia which is similar to our results. Similar observation-based results from India suggest surface forcing of $-23 \mathrm{~W} \mathrm{~m}^{-2}$ and TOA forcing of $5 \mathrm{~W} \mathrm{~m}^{-2}$ by enhanced $\mathrm{BC}$ over the urban environment (Babu et al., 2002). Variation within the two months shows the sensitivity of forcing based on the emissions and subsequent concentrations.

Sharma et al. (2010) have reported a total surface radiative flux of $-134 \mathrm{~W} \mathrm{~m}^{-2}$ to $-212 \mathrm{~W} \mathrm{~m}^{-2}$ and TOA radiative flux of $-41 \mathrm{~W} \mathrm{~m}^{-2}$ to $-47 \mathrm{~W} \mathrm{~m}^{-2}$ over Punjab for the month of October (2006-2007). Our study estimates changes in OLR flux over Punjab to be $\sim-0.48 \mathrm{~W} \mathrm{~m}^{-2}$ for the entire region. The model reports area-averaged surface forcing to be 0.008 to $-78.21 \mathrm{~W} \mathrm{~m}^{-2}$ and OLR at TOA to be -4.96 to $2.48 \mathrm{~W} \mathrm{~m}^{-2}$ over Punjab which is comparable with the observations. The regional $\mathrm{BC}$ radiative forcing at the surface in the 1990s was estimated to be between $-30 \mathrm{~W} \mathrm{~m}^{-2}$ to $-20 \mathrm{~W} \mathrm{~m}^{-2}$ over northern BoB (Ramanathan et al., 2001; Krishnan and Ramanathan, 2002; Ramanathan et al., 2005) while a total aerosol forcing of $\sim-75 \mathrm{~W} \mathrm{~m}^{-2}$ was reported for the same time period by Lelieveld et al. (2001). The surface radiative forcing reported by Chung et al. (2010) due to anthropogenic aerosol is $-8.6 \mathrm{~W} \mathrm{~m}^{-2}$ and $-5.2 \mathrm{~W} \mathrm{~m}^{-2}$ by BC over Asia. Our results provide insight into the contribution of carbonaceous aerosol which has similar emission sources and patterns, unlike the previous studies that either focus on a single aerosol or total aerosol effect. Our results show that carbonaceous aerosols from open biomass burning strongly alter radiation balance in the atmosphere at a local and regional level.

Carbonaceous aerosols from OBB shows a strong influence on surface incoming shortwave flux over Myanmar and Punjab (Table 3), which indicates less radiation is reaching to surface. Such a strong reduction in radiation at the surface make a negative change in temperature, which is further justified in Fig. 4, where the temperature drops significantly even as other factors also change. Similar results are presented by Ding et al. (2013) for China where the drops in temperature up to $10 \mathrm{~K}$ is reported during $\mathrm{OBB}$ and high-pollution events.

Fig. 4 depicts the domain-averaged OBB carbonaceous aerosol impact on surface weather parameters over Punjab and Myanmar. Figs. 4(a)-4(b) shows the time series of OBB carbonaceous aerosol concentration while the rest show changes in meteorological parameters. The results show that changes are proportional to surface concentration. Lower concentration of carbonaceous aerosol from fire over both Myanmar and Punjab do not make significant impacts on the meteorological parameters. Wind speed (Figs. 4(c)-4(d)) shows both positive and negative changes, RH (Figs. 4(e)-4(f)) shows an increase in values while temperature (Figs. 4(g)4(h)) and PBL height (Figs. 4(i)-4(j)) show a decrease in magnitude. The magnitude of the surface temperature change is up to $2 \mathrm{~K}$. RH values change by up to $8 \%$. The increase in relative humidity $(\mathrm{RH})$ is due to high moist static energy during biomass burning events as, during this period, high evaporation rate (Ma et al., 2015) and shallow PBL height result in higher RH (Ding et al., 2013). The magnitude of wind speed is change between -0.6 to $0.3 \mathrm{~m} \mathrm{~s}^{-1}$ with decreasing wind speed most of the time. The PBL height significantly changes from 200 to $600 \mathrm{~m}$ during OBB period.

Krishnan and Ramanathan (2002) suggest that a 10-15\% increase in $\mathrm{BC}$ concentration can block up to $10 \%$ solar radiation which leads to $0.3^{\circ} \mathrm{C}$ cooling at surface. They further note that the observed cooling may lead to warming elsewhere. Wilcox et al. (2016) suggested up to $8 \%$ increase in relative humidity during polluted period. In Balachandran et al. (2017), fire $\mathrm{PM}_{2.5}$ had an inverse relationship with variables like PBL and wind speed similar to our results.

Fig. 5 shows a temperature difference (monthly average) due to OBB-emitted carbonaceous aerosol at different vertical layers. Given the higher difference in OBB carbonaceous aerosol concentration over Myanmar compared to Punjab, the changes in surface and $850 \mathrm{hPa}$ temperature is stronger over Myanmar than Punjab. Small rises in temperature are seen over the northwestern domain during the month of April and over the eastern portion of the domain in November possibly due to changed circulation. Smaller temperature changes are simulated over the entire domain during the month of April at $500 \mathrm{hPa}$ and $300 \mathrm{hPa}$, while other months show very little or localized change at these altitudes.

Table 3. Radiative forcing from OBB carbonaceous aerosol over Myanmar and Punjab.

\begin{tabular}{|c|c|c|c|c|c|}
\hline \multirow[b]{2}{*}{ Region } & \multirow[b]{2}{*}{ Month } & \multicolumn{2}{|c|}{ Domain area average effect } & \multicolumn{2}{|c|}{ Local area average effect } \\
\hline & & $\begin{array}{l}\text { Surface } \\
\text { incoming } \\
\text { shore wave } \\
\text { flux }\left(\mathrm{W} \mathrm{m}^{-2}\right)\end{array}$ & $\begin{array}{l}\text { TOA outgoing } \\
\text { longwave } \\
\text { wave flux } \\
\left(\mathrm{W} \mathrm{m}^{-2}\right)\end{array}$ & $\begin{array}{l}\text { Surface } \\
\text { incoming } \\
\text { shore wave } \\
\text { flux }\left(\mathrm{W} \mathrm{m}^{-2}\right)\end{array}$ & $\begin{array}{l}\text { TOA outgoing } \\
\text { longwave } \\
\text { wave flux } \\
\left(\mathrm{W} \mathrm{m}^{-2}\right)\end{array}$ \\
\hline Myanmar & March & -8.05 & -0.28 & -42.76 & -1.91 \\
\hline$\left(13.86-27.74^{\circ} \mathrm{N}, 90.28-102.69^{\circ} \mathrm{E}\right)$ & April & -6.78 & -0.1 & -29.16 & -0.52 \\
\hline Punjab & October & -0.45 & -0.02 & -5.13 & -0.48 \\
\hline$\left(28.83-32.04^{\circ} \mathrm{N}, 72.91-77.86 \mathrm{E}\right)$ & November & -1.34 & -0.06 & -6.14 & -0.50 \\
\hline
\end{tabular}




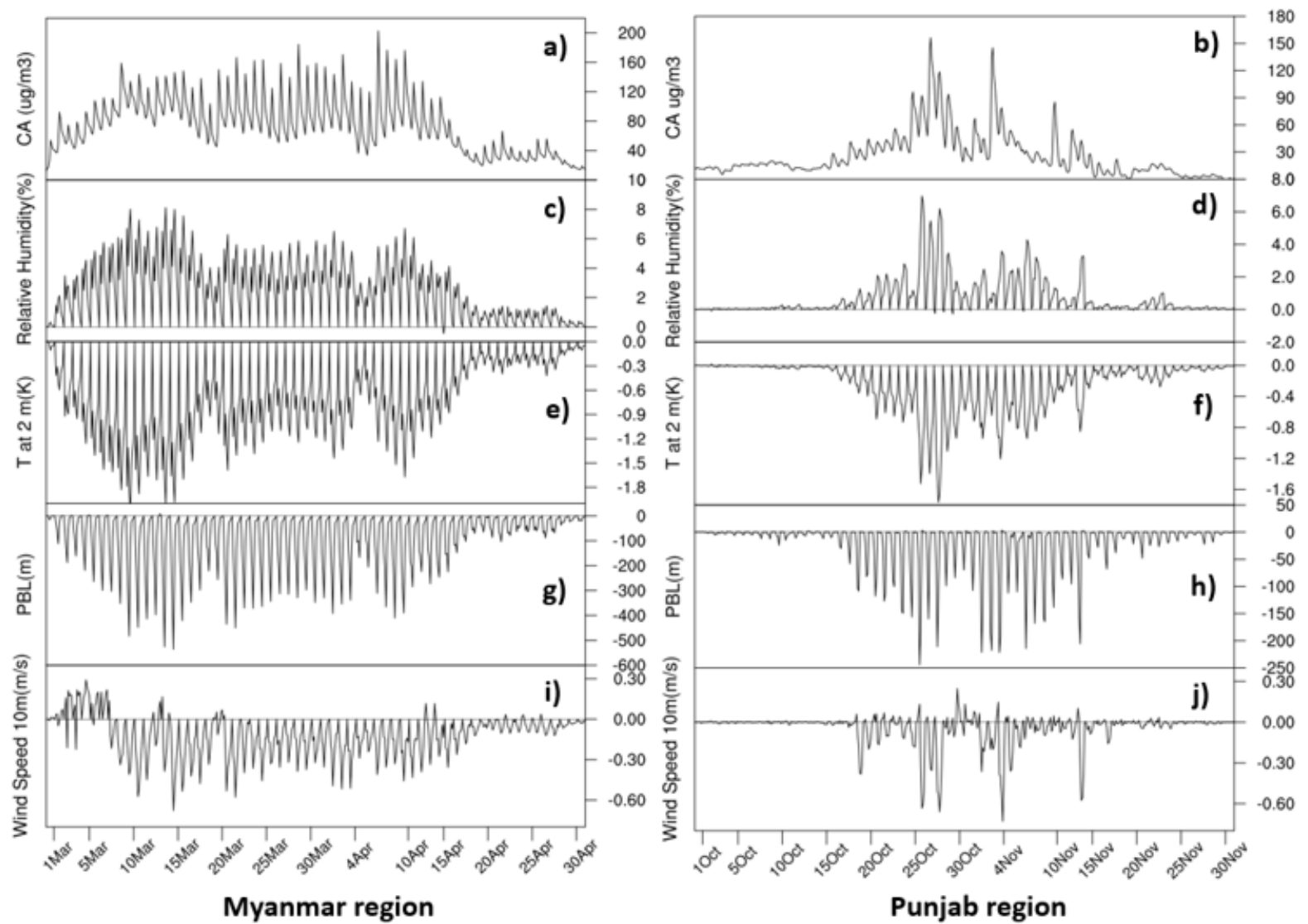

Fig. 4. Effect of (a-b) OBB carbonaceous aerosol concentration on (c-d) 2 m relative humidity, (e-f) $2 \mathrm{~m}$ temperature, (gh) PBL height and (i-j) $10 \mathrm{~m}$ wind speed for Myanmar and Punjab respectively.
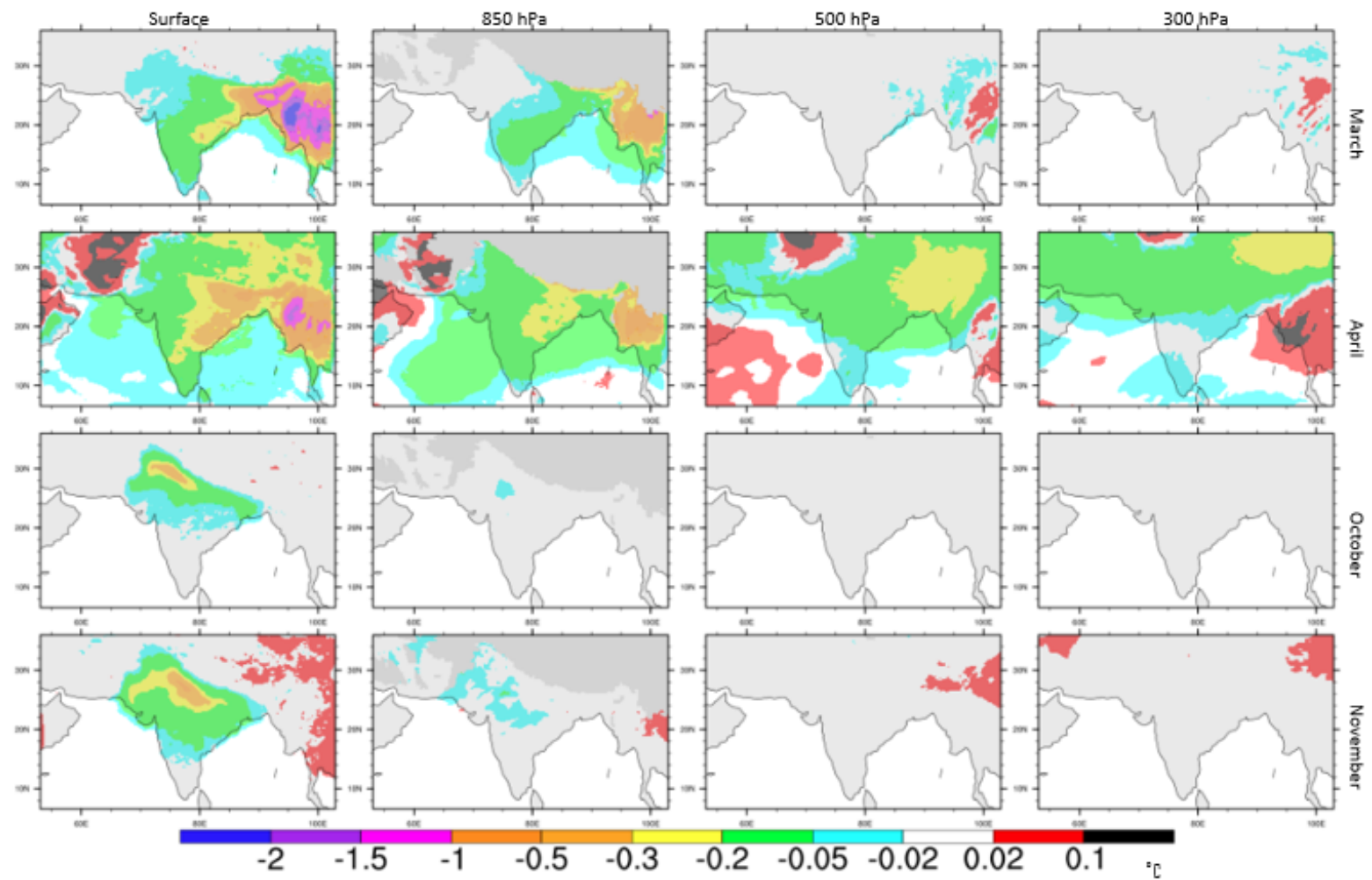

Fig. 5. Effect of carbonaceous aerosol from OBB on temperature at different pressure level: (a) surface, (b) $850 \mathrm{hPa}$, (c) $500 \mathrm{hPa}$ and (d) $300 \mathrm{hPa}$. 
Balachandran et al. (2017) and Saha et al. (2014) have also reported changes in PBL and other meteorological variables due to aerosol radiative feedback which could lead to warming elsewhere. Finally, our study suggests that carbonaceous aerosol $(\mathrm{BC}+\mathrm{OC})$ also reduces surface temperature similar to $\mathrm{BC}$ despite the scattering effects of organic carbon.

We also examined the impact of OBB carbonaceous aerosol on precipitation amount and pattern over South Asia. OBB occurs during the pre-monsoon and post-monsoon season in South Asia, a period when there is no significant precipitation over the subcontinent. Previous studies have reported on the impact of aerosols, especially $\mathrm{BC}$, on changes in monsoon precipitation later on during the season (Manoj et al., 2011). In this study, we analyzed fast response to precipitation amount and pattern. Our results indicate that there is no significant change in either amount or pattern of precipitation over the modeling domain; a $\sim 2-5 \%$ change is simulated near Myanmar, which is limited to a few grids (Supporting Fig. S4). We wish to point out that the study only considered direct effects through radiative forcing and did not examine the aerosol cloud interaction and pathways for changes in precipitation. The PDRMIP multi-model study also suggested that the effect of $10 \times \mathrm{BC}$ on Asian precipitation is very small $(\sim 1.4 \%)$ (Liu et al., 2018) similar to the results of this study.

\section{SUMMARY AND CONCLUSION}

Climatological data from the GFED4, CAMS and FINN fire products identifies Punjab and Myanmar as major emitters of carbonaceous aerosol from open biomass burning, as well as several smaller sources in South Asia. The primary contributor to open biomass burning emissions in this region is Myanmar forest fires, which occur from March to April, when the weather is dry and hot. Myanmar forest fires alone emit $\sim 0.80 \mathrm{~g} \mathrm{~m}^{-2}$ month $^{-1}$ of CA, whereas the total carbon emissions equal $\sim 12.71 \mathrm{~g} \mathrm{~m}^{-2}$ month $^{-1}$. Additionally, although April-May and October-November are observed to be the agricultural residue burning seasons in Punjab, both GFED4 and FINN show higher CA $\left(\sim 0.12 \mathrm{~g} \mathrm{~m}^{-2}\right.$ month $\left.^{-1}\right)$ and carbon $\left(\sim 5.59 \mathrm{~g} \mathrm{~m}^{-2}\right.$ month $\left.^{-1}\right)$ emissions from October to November over this region. Compared to the FINN estimates, CA emissions from Myanmar and Punjab increase by up to 30 times and up to 2-3 times during OBB, respectively.

The area-averaged time series vertical profile of the carbonaceous aerosol concentration indicates that the bulk of the aerosol is lofted to an altitude of 3-5 km. Specificevents transport plumes even higher, and the simulated concentrations affect even the $300 \mathrm{hPa}$ level. The vertical transport of plumes depends entirely on PBL mixing and thermodynamic stability in the atmosphere. During the Myanmar fire season (March-April), the PBL is high, and more vertical transport is visible due to active convection in this region. By contrast, the PBL over Punjab is shallower from October to November than during the rest of the season, and the atmosphere remains stable; thus, significantly less vertical transport is evident. Uncertainty in the PBL height and thermodynamic parameterization may affect the vertical plume height of the OBB emission and transport, and PBL aerosol feedback can also affect the concentration at lower levels. A shallower PBL may reduce dispersion, leading to higher aerosol concentrations, whereas a high PBL facilitates the mixing of aerosol, enabling more dispersion and thereby potentially reducing concentrations in the PBL. Radiative forcing calculations demonstrate that carbonaceous aerosol contributed $-6.14 \mathrm{~W} \mathrm{~m}^{-2}$ and $-0.50 \mathrm{~W} \mathrm{~m}^{-2}$, and $-42.76 \mathrm{~W} \mathrm{~m}^{-2}$ and $-1.91 \mathrm{~W} \mathrm{~m}^{-2}$ at the surface and at the TOA, respectively, over Punjab and Myanmar. These results are similar to estimates of the $\mathrm{BC}$ and total aerosol forcing from previous studies. This study is the first report on radiative forcing that considers the combined effects of carbonaceous aerosol (BC + OC) from open fires, which contributes to significant loading in the atmosphere during active burning. Because $\mathrm{BC}$ and $\mathrm{OC}$ interact with radiation differently, however, quantifying the effect of each on the incoming and outgoing radiation flux must be addressed in future studies. The effect of carbonaceous aerosols on the incoming and outgoing radiation flux produces changes in meteorological parameters, such as the surface temperature decreasing by $2 \mathrm{~K}$, the $\mathrm{RH}$ increasing by $8 \%$ and the PBL height changing by up to $600 \mathrm{~m}$, which are proportional to the carbonaceous aerosol concentrations during biomass burning events. However, since we adhered to the control run estimates of anthropogenic and fire emissions, changes in the precipitation patterns and volume were negligible when considering only the direct radiative feedback.

This study discovers a radiative impact from carbonaceous aerosol generated from open biomass burning that is similar to the effect from the total (anthropogenic + biomass) BC aerosol. Although our research is limited in determining the meteorological effects, it reveals the strong influence of carbonaceous aerosol on local meteorological parameters, including the inhibition of pollution dispersion. The negative feedback between the carbonaceous aerosol, and the PBL and the temperature leads to positive feedback with the aerosol concentration, leading to severe pollution events in the IGP region during winter. Future studies could explore the impact on circulation patterns and atmospheric composition. Moreover, these results are based on a year-long study but may vary intra-annually. Aerosol-cloud interaction schemes in the model may also be applied to further explore the impacts of OBB-emitted CA on precipitation patterns.

\section{ACKNOWLEDGEMENT}

ICIMOD gratefully acknowledges the support of its core donors: the governments of Afghanistan, Australia, Austria, Bangladesh, Bhutan, China, India, Myanmar, Nepal, Norway, Pakistan, Sweden, and Switzerland.

\section{DISCLAIMER}

The views and interpretations in this publication are those of the authors and are not necessarily attributable to ICIMOD.

\section{SUPPLEMENTARY MATERIAL}

Supplementary data associated with this article can be 
found in the online version at http://www.aaqr.org.

\section{REFERENCES}

Adhikary, B., Carmichael, G.R., Tang, Y., Leung, L.R., Qian, Y., Schauer, J.J., Stone, E.A., Ramanathan, V. and Ramana, M.V (2007). Characterization of the seasonal cycle of south Asian aerosols : A regional-scale modeling analysis. J. Geophys. Res. 112: D22S22.

Andrews, T., Forster, P.M., Boucher, O., Bellouin, N. and Jones, A. (2010). Precipitation, radiative forcing and global temperature change. Geophys. Res. Lett. 37: L14701.

Archer-Nicholls, S., Lowe, D., Darbyshire, E., Morgan, W.T., Bela, M.M., Pereira, G., Trembath, J., Kaiser, J.W., Longo, K.M., Freitas, S.R., Coe, H. and McFiggans, G. (2015). Characterising Brazilian biomass burning emissions using WRF-Chem with MOSAIC sectional aerosol. Geosci. Model Dev. 8: 549-577.

Babu, S.S., Satheesh, S.K. and Moorthy, K.K. (2002). Aerosol radiative forcing due to enhanced black carbon at an urban site in India. Geophys. Res. Lett. 29: 27-1-27-4.

Balachandran, S., Baumann, K., Pachon, J.E., Mulholland, J.A. and Russell, A.G. (2017). Evaluation of fire weather forecasts using $\mathrm{PM}_{2.5}$ sensitivity analysis. Atmos. Environ. 148: 128-138.

Biswas, S., Vadrevu, K.P., Lwin, Z.M., Lasko, K. and Justice, C.O. (2015). Factors controlling vegetation fires in protected and non-protected areas of Myanmar. PLoS One 10: e0124346.

Bond, T.C., Bhardwaj, E., Dong, R., Jogani, R., Jung, S., Roden, C., Streets, D.G. and Trautmann, N.M. (2007). Historical emissions of black and organic carbon aerosol from energy-related combustion, 1850-2000. Global Biogeochem. Cycles 21: GB2018.

Bond, T.C., Doherty, S.J., Fahey, D.W., Forster, P.M., Berntsen, T., DeAngelo, B.J., Flanner, M.G., Ghan, S., Kärcher, B., Koch, D., Kinne, S., Kondo, Y., Quinn, P.K., Sarofim, M.C., Schultz, M.G., Schulz, M., Venkataraman, C., Zhang, H., Zhang, S., Bellouin, N., Guttikunda, S.K., Hopke, P.K., Jacobson, M.Z., Kaiser, J.W., Klimont, Z., Lohmann, U., Schwarz, J.P., Shindell, D., Storelvmo, T., Warren, S.G. and Zender, C.S. (2013). Bounding the role of black carbon in the climate system: A scientific assessment. J. Geophys. Res. 118: 5380-5552

Chang, D. and Song, Y. (2010). Estimates of biomass burning emissions in tropical Asia based on satellitederived data. Atmos. Chem. Phys. 10: 2335-2351.

Chen, Y. and Bond, T.C. (2010). Light absorption by organic carbon from wood combustion. Atmos. Chem. Phys. 10: 1773-1787.

Chin, M., Rood, R.B., Lin, S.J., Müller, J.F. and Thompson, A.M. (2000). Atmospheric sulfur cycle simulated in the global model GOCART: Model description and global properties. J. Geophys. Res. 105: 24671-24687.

Chung, C.E., Ramanathan, V., Qian, Y., Adhikary, B., Leung, L.R., Carmichael, G., Kulkarni, S. and Tang, Y. (2010). Anthropogenic aerosol radiative forcing in Asia derived from regional models with atmospheric and aerosol data assimilation. Atmos. Chem. Phys. 10: 6007-
6024.

Conant, W.C., Nenes, A. and Seinfeld, J.H. (2002). Black carbon radiative heating effects on cloud microphysics and implications for the aerosol indirect effect. 1. Extended Köhler theory. J. Geophys. Res. 107: 4604.

Di Giuseppe, F., Rémy, S., Pappenberger, F. and Wetterhall, F. (2018). Using the Fire Weather Index (FWI) to improve the estimation of fire emissions from fire radiative power (FRP) observations. Atmos. Chem. Phys. 18: 5359-5370.

Ding, A.J., Fu, C.B., Yang, X.Q., Sun, J.N., Petäjä, T., Kerminen, V.M., Wang, T., Xie, Y., Herrmann, E., Zheng, L.F., Nie, W., Liu, Q., Wei, X.L. and Kulmala, M. (2013). Intense atmospheric pollution modifies weather: A case of mixed biomass burning with fossil fuel combustion pollution in eastern China. Atmos. Chem. Phys. 13: 10545-10554.

Dudhia, J. (1989). Numerical study of convection observed during the Winter Monsoon Experiment using a mesoscale two-dimensional model. J. Atmos. Sci. 46: 3077-3107.

Duncan, B.N. (2003). Interannual and seasonal variability of biomass burning emissions constrained by satellite observations. J. Geophys. Res. 108: 4100.

Ellison, G.B., Tuck, A.F. and Vaida, V. (1999). Atmospheric processing of organic aerosols. J. Geophys. Res. 104: 11633-11641.

Emmons, L.K., Walters, S., Hess, P.G., Lamarque, J.F., Pfister, G.G., Fillmore, D., Granier, C., Guenther, A., Kinnison, D., Laepple, T., Orlando, J., Tie, X., Tyndall, G., Wiedinmyer, C., Baughcum, S.L. and Kloster, S. (2010). Description and evaluation of the Model for Ozone and Related chemical Tracers, version 4 (MOZART-4). Geosci. Model Dev. 3: 43-67.

Giglio, L., Randerson, J.T. and Van Der Werf, G.R. (2013). Analysis of daily, monthly, and annual burned area using the fourth-generation global fire emissions database (GFED4). J. Geophys. Res. 118: 317-328.

Goldammer, J.G., Statheropoulos, M. and Andreae, M.O. (2008). Chapter 1 impacts of vegetation fire emissions on the environment, human health, and security: A global perspective. Dev. Environ. Sci. 8: 3-36.

Grell, G.A., Peckham, S.E., Schmitz, R., Mckeen, S.A., Frost, G., Skamarock, W.C. and Eder, B. (2005). Fully coupled " online" "chemistry within the WRF model. Atmos. Environ. 39: 6957-6975.

Grell, G., Freitas, S.R., Stuefer, M. and Fast, J. (2011). Inclusion of biomass burning in WRF-Chem: Impact of wildfires on weather forecasts. Atmos. Chem. Phys. 11: 5289-5303.

Guenther, A.B., Jiang, X., Heald, C.L., Sakulyanontvittaya, T., Duhl, T., Emmons, L.K. and Wang, X. (2012). The model of emissions of gases and aerosols from nature version 2.1 (MEGAN2.1): An extended and updated framework for modeling biogenic emissions. Geosci. Model Dev. 5: 1471-1492.

Guha, A., De, B.K., Dhar, P., Banik, T., Chakraborty, M., Roy, R., Choudhury, A., Gogoi, M.M., Babu, S.S. and Moorthy, K.K. (2015). Seasonal characteristics of aerosol black carbon in relation to long range transport over 
Tripura in Northeast India. Aerosol Air Qual. Res. 15: 786-798.

Hansen, J. and Nazarenko, L. (2004). Soot climate forcing via snow and ice albedos. PNAS 101: 423-428.

Haywood, J.M., Pelon, J., Formenti, P., Bharmal, N., Brooks, M., Capes, G., Chazette, P., Chou, C., Christopher, S., Coe, H., Cuesta, J., Derimian, Y., Desboeufs, K., Greed, G., Harrison, M., Heese, B., Highwood, E.J., Johnson, B., Mallet, M., Marticorena, B., Marsham, J., Milton, S., Myhre, G., Osborne, S.R., Parker, D.J., Rajot, J.L., Schulz, M., Slingo, A., Tanré, D. and Tulet, P. (2008). Overview of the dust and biomass-burning experiment and African monsoon multidisciplinary analysis special observing period-0. J. Geophys. Res. 113: D00C17.

Hoelzemann, J.J., Schultz, M.G., Brasseur, G.P., Granier, C. and Simon, M. (2004). Global Wildland Fire Emission Model (GWEM): Evaluating the use of global area burnt satellite data. J. Geophys. Res. 109: D14S04.

Hong, S.Y., Noh, Y. and Dudhia, J. (2006). A new vertical diffusion package with an explicit treatment of entrainment processes. Mon. Weather Rev. 134: 2318-2341.

Jain, N., Bhatia, A. and Pathak, H. (2014). Emission of air pollutants from crop residue burning in India. Aerosol Air Qual. Res. 14: 422-430.

Janssens-Maenhout, G., Pagliari, V., Guizzardi, D. and Muntean, M. (2013). Global Emission Inventories in the Emission Database for Global Atmospheric Research (Edgar)-Manual (I). Gridding: EDGAR emissions distribution on global gridmaps, Publications Office of the European Union, Luxembourg.

Kain, J.S. (2004). The Kain-Fritsch convective parameterization: An update. J. Appl. Meteorol. 43: 170181.

Karl, T., Guenther, A., Yokelson, R.J., Greenberg, J., Potosnak, M., Blake, D.R. and Artaxo, P. (2007). The tropical forest and fire emissions experiment: Emission, chemistry, and transport of biogenic volatile organic compounds in the lower atmosphere over Amazonia. $J$. Geophys. Res. 112: D18302.

Kim Oanh, N.T., Permadi, D.A., Hopke, P.K., Smith, K.R., Dong, N.P. and Dang, A.N. (2018). Annual emissions of air toxics emitted from crop residue open burning in Southeast Asia over the period of 2010-2015. Atmos. Environ. 187: 163-173.

Koch, D. and Del Genio, A.D. (2010). Black carbon semidirect effects on cloud cover: Review and synthesis. Atmos. Chem. Phys. 10: 7685-7696.

Kondo, Y., Matsui, H., Moteki, N., Sahu, L., Takegawa, N., Kajino, M., Zhao, Y., Cubison, M.J., Jimenez, J.L., Vay, S., Diskin, G.S., Anderson, B., Wisthaler, A., Mikoviny, T., Fuelberg, H.E., Blake, D.R., Huey, G., Weinheimer, A.J., Knapp, D.J. and Brune, W.H. (2011). Emissions of black carbon, organic, and inorganic aerosols from biomass burning in North America and Asia in 2008. J. Geophys. Res. 116: D08204.

Krishnan, R. and Ramanathan, V. (2002). Evidence of surface cooling from absorbing aerosols. Geophys. Res. Lett. 29: 54-1-54-4.

Kumar, R., Barth, M.C., Pfister, G.G., Nair, V.S., Ghude,
S.D. and Ojha, N. (2015). What controls the seasonal cycle of black carbon aerosols in India? J. Geophys. Res. 120: 7788-7812.

Lee, J., Christina Hsu, N., Bettenhausen, C., Sayer, A.M., Seftor, C.J., Jeong, M.J., Tsay, S.C., Welton, E.J., Wang, S.H. and Chen, W.N. (2016). Evaluating the height of biomass burning smoke aerosols retrieved from synergistic use of multiple satellite sensors over southeast Asia. Aerosol Air Qual. Res. 16: 2831-2842.

Lelieveld, J., Crutzen, P.J., Ramanathan, V., Andreae, M.O., Brenninkmeijer, C.A.M., Campos, T., Cass, G.R., Dickerson, R.R., Fischer, H., de Gouw, J.A., Hansel, A., Jefferson, A., Kley, D., de Laat, A.T.J., Lal, S., Lawrence, M.G., Lobert, J.M., Mayol-Bracero, O.L., Mitra, A.P., Novakov, T., Oltmans, S.J., Prather, K.A., Reiner, T., Rodhe, H., Scheeren, H.A., Sikka, D. and Williams, J. (2001). The Indian Ocean experiment: Widespread air pollution from South and Southeast Asia. Science 291: 1031-1036.

Lin, C.Y., Hsu, H.M., Lee, Y.H., Kuo, C.H., Sheng, Y.F. and Chu, D.A. (2009). A new transport mechanism of biomass burning from Indochina as identified by modeling studies. Atmos. Chem. Phys. 9: 7901-7911.

Liu, L., Shawki, D., Voulgarakis, A., Kasoar, M., Samset, B.H., Myhre, G., Forster, P.M., Hodnebrog, Ø., Sillmann, J., Aalbergsjø, S.G., Boucher, O., Faluvegi, G., Iversen, T., Kirkevåg, A., Lamarque, J.F., Olivié, D., Richardson, T., Shindell, D. and Takemura, T. (2018). A PDRMIP Multimodel study on the impacts of regional aerosol forcings on global and regional precipitation. J. Clim. 31: 4429-4447.

Liu, Y., Stanturf, J. and Goodrick, S. (2010). Trends in global wildfire potential in a changing climate. For. Ecol. Manage. 259: 685-697.

Liu, Y., Goodrick, S. and Heilman, W. (2014). Wildland fire emissions, carbon, and climate: Wildfire-climate interactions. For. Ecol. Manage. 317: 80-96.

Ma, Z., Fei, J., Huang, X. and Cheng, X. (2015). A potential problem with the application of moist static energy in tropical cyclone studies. Am. Meteorol. Soc. 72: 30093019.

Madronich, S. and Weller, G. (1990). Numerical integration errors in calculated tropospheric photodissociation rate coefficients. J. Atmos. Chem. 10: 289-300.

Manoj, M.G., Devara, P.C.S., Safai, P.D. and Goswami, B.N. (2011). Absorbing aerosols facilitate transition of Indian monsoon breaks to active spells. Clim. Dyn. 37: 21812198

Mlawer, E.J., Taubman, S.J., Brown, P.D., Iacono, M.J. and Clough, S.A. (1997). Radiative transfer for inhomogeneous atmospheres: RRTM, a validated correlated-k model for the longwave. J. Geophys. Res. 102: 16663-16682.

O'Gorman, P.A., Allan, R.P., Byrne, M.P. and Previdi, M. (2012). Energetic constraints on precipitation under climate change. Surv. Geophys. 33: 585-608.

Paulson, C.A. (1970). The mathematical representation of wind speed and temperature profiles in the unstable atmospheric surface layer. J. Appl. Meteorol. 9: 857-861.

Penner, J. (1994). Carbonaceous aerosols influencing 
atmospheric radiation: Black and organic carbon. In Aerosol Forcing of Climate, Charlson, R.J. and Heintzenberg, J. (Eds.), John Wiley and Sons, New York, pp. 91-108.

Potter, C., Brooks Genovese, V., Klooster, S., Bobo, M. and Torregrosa, A. (2001). Biomass burning losses of carbon estimated from ecosystem modeling and satellite data analysis for the Brazilian Amazon region. Atmos. Environ. 35: 1773-1781.

Putero, D., Landi, T.C., Cristofanelli, P., Marinoni, A., Laj, P., Duchi, R., Calzolari, F., Verza, G.P. and Bonasoni, P. (2014). Influence of open vegetation fires on black carbon and ozone variability in the southern Himalayas (NCO-P, 5079 m a.s.1.). Environ. Pollut. 184: 597-604.

Rajput, P., Sarin, M., Sharma, D. and Singh, D. (2014). Characteristics and emission budget of carbonaceous species from post-harvest agricultural-waste burning in source region of the Indo-Gangetic plain. Tellus B 66: 1 .

Ramanathan, V., Crutzen, P.J., Lelieveld, J., Mitra, A.P., Althausen, D., Anderson, J., Andreae, M.O., Cantrell, W., Cass, G.R., Chung, C.E., Clarke, A.D., Coakley, J.A., Collins, W.D., Conant, W.C., Dulac, F., Heintzenberg, J., Heymsfield, A.J., Holben, B., Howell, S., Hudson, J., Jayaraman, A., Kiehl, J.T., Krishnamurti, T.N., Lubin, D., McFarquhar, G., Novakov, T., Ogren, J.A., Podgorny, I.A., Prather, K., Priestley, K., Prospero, J.M., Quinn, P.K., Rajeev, K., Rasch, P., Rupert, S., Sadourny, R., Satheesh, S.K., Shaw, G.E., Sheridan, P. and Valero, F.P.J. (2001). Indian Ocean Experiment: An integrated analysis of the climate forcing and effects of the great Indo-Asian haze. J. Geophys. Res. 106: 28371-28398.

Ramanathan, V., Chung, C., Kim, D., Bettge, T., Buja, L., Kiehl, J.T., Washington, W.M., Fu, Q., Sikka, D.R. and Wild, M. (2005). Atmospheric brown clouds: Impacts on South Asian climate and hydrological cycle. PNAS 102: 5326-5333.

Ramanathan, V. and Carmichael, G. (2008). Global and regional climate changes due to black carbon. Nat. Geosci. 1: 221-227.

Reddington, C.L., Yoshioka, M., Balasubramanian, R., Ridley, D., Toh, Y.Y., Arnold, S.R. and Spracklen, D.V. (2014). Contribution of vegetation and peat fires to particulate air pollution in Southeast Asia. Environ. Res. Lett. 9: 094006.

Reddy, B.S.K., Kumar, K.R., Balakrishnaiah, G., Gopal, K.R., Reddy, R., Reddy, L., Ahammed, Y.N., Narasimhulu, K., Moorthy, K.K. and Babu, S.S. (2012). Potential source regions contributing to seasonal variations of black carbon aerosols over Anantapur in southeast India. Aerosol Air Qual. Res. 12: 344-358.

Reid, J.S., Hobbs, P.V., Liousse, C., Martins, J.V., Weiss, R.E., and Eck, T.F. ( 1998), Comparisons of techniques for measuring shortwave absorption and black carbon content of aerosols from biomass burning in Brazil. $J$. Geophys. Res. 10: 32031-32040.

Saha, U., Talukdar, S., Jana, S. and Maitra, A. (2014). Effects of air pollution on meteorological parameters during deepawali festival over an Indian urban metropolis Atmos. Environ. 98: 530-539.
Sahu, L.K., Sheel, V., Pandey, K., Yadav, R., Saxena, P. and Gunthe, S. (2015). Regional biomass burning trends in India: Analysis of satellite fire data. J. Earth Syst. Sci. 124: $1377-1387$.

Sharma, A.R., Kharol, S.K., Badarinath, K.V.S. and Singh, D. (2010). Impact of agriculture crop residue burning on atmospheric aerosol loading - A study over Punjab State, India. Ann. Geophys. 28: 367-379.

Sharma, M., Kaskaoutis, D.G., Singh, R.P. and Singh, S. (2014). Seasonal variability of atmospheric aerosol parameters over greater Noida using ground sunphotometer observations. Aerosol Air Qual. Res. 14: 608-622.

Singh, R.P. and Kaskaoutis, D.G. (2014). Crop residue burning: A threat to south asian air quality. EOS, American Geophys. Union 95.

Skamarock, W.C., Klemp, J.B., Dudhi, J., Gill, D.O., Barker, D.M., Duda, M.G., Huang, X.Y., Wang, W. and Powers, J.G. (2008). A description of the advanced research WRF Version 3. NCAR Tech. Note NCAR/TN-468+STR, 113 pp. NCAR Tech. NOTE.

Song, Y., Chang, D., Liu, B., Miao, W., Zhu, L. and Zhang, Y. (2010). A new emission inventory for nonagricultural open fires in Asia from 2000 to 2009. Environ. Res. Lett. 5: 014014

Streets, D.G., Bond, T.C., Carmichael, G.R., Fernandes, S.D., Fu, Q., He, D., Klimont, Z., Nelson, S.M., Tsai, N.Y., Wang, M.Q., Woo, J.H. and Yarber, K.F. (2003a). An inventory of gaseous and primary aerosol emissions in Asia in the year 2000. J. Geophys. Res. 108: 8809.

Streets, D.G., Yarber, K.F., Woo, J.H. and Carmichael, G.R. (2003b). Biomass burning in Asia: Annual and seasonal estimates and atmospheric emissions. Global Biogeochem. Cycles 17: 1099.

Tewari, M.F., Chen, W., Wang, J., Dudhia, M.A., LeMone, K., Mitchell, M.E., Gayno, G., Wegiel, J. and Cuenca, R.H. (2004). Implementation and verification of the unified noah land surface model in the WRF model. $20^{\text {th }}$ Conference on Weather Analysis and Forecasting $/ 16^{\text {th }}$ Conference on Numerical Weather Prediction, American Meteorological Society, Seattle, WA, US.

Thompson, G., Field, P.R., Rasmussen, R.M. and Hall, W.D. (2008). Explicit forecasts of winter precipitation using an improved bulk microphysics scheme. Part II: Implementation of a new snow parameterization. Mon. Weather Rev. 136: 5095-5115.

Tiwari, S., Kumar, R., Tunved, P., Singh, S. and Panicker, A.S. (2016). Significant cooling effect on the surface due to soot particles over Brahmaputra River Valley region, India: An impact on regional climate. Sci. Total Environ. 562: 504-516.

Vadrevu, K.P., Lasko, K., Giglio, L. and Justice, C. (2015). Vegetation fires, absorbing aerosols and smoke plume characteristics in diverse biomass burning regions of Asia. Environ. Res. Lett. 10: 105003.

Vadrevu, K. and Lasko, K. (2018). Intercomparison of MODIS AQUA and VIIRS I-band fires and emissions in an agricultural landscape-implications for air pollution research. Remote Sens. 10: 978.

Venkataraman, C., Habib, G., Kadamba, D., Shrivastava, M., 
Leon, J.F., Crouzille, B., Boucher, O. and Streets, D.G. (2006). Emissions from open biomass burning in India: Integrating the inventory approach with high-resolution Moderate Resolution Imaging Spectroradiometer (MODIS) active-fire and land cover data. Global Biogeochem. Cycles 20: GB2013.

Walter, C., Freitas, S.R., Kottmeier, C., Kraut, I., Rieger, D., Vogel, H. and Vogel, B. (2016). The importance of plume rise on the concentrations and atmospheric impacts of biomass burning aerosol. Atmos. Chem. Phys. 16: 92019219.

Wiedinmyer, C., Akagi, S.K., Yokelson, R.J., Emmons, L.K., Al-Saadi, J.A., Orlando, J.J. and Soja, A.J. (2011). The Fire INventory from NCAR (FINN): A high resolution global model to estimate the emissions from open burning. Geosci. Model Dev. 4: 625-641.

Wilcox, E.M., Thomas, R.M., Praveen, P.S., Pistone, K.,
Bender, F.A.M. and Ramanathan, V. (2016). Black carbon solar absorption suppresses turbulence in the atmospheric boundary layer. PNAS 113: 11794-11799.

Zhang, R., Wang, H., Qian, Y., Rasch, P.J., Easter, R.C., Ma, P.L., Singh, B., Huang, J. and Fu, Q. (2015). Quantifying sources, transport, deposition, and radiative forcing of black carbon over the Himalayas and Tibetan Plateau. Atmos. Chem. Phys. 15: 6205-6223.

Zhou, J., Tie, X., Xu, B., Zhao, S., Wang, M. and Li, G. (2018). Black carbon (BC) in North Tibetan Mountain; Effect of Kuwait fires on glacier. Atmos. Chem. Phys. 18: 13673-13685.

Received for review, April 16, 2019 Revised, October 19, 2019 Accepted, December 5, 2019 